DOI: http://dx.doi.org/10.33846/hn40103

http://heanoti.com/index.php/hn

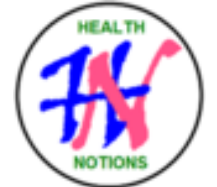

RESEARCH ARTICLE

URL of this article: http://heanoti.com/index.php/hn/article/view/hn40103

\title{
Relationship Between Working Mothers towards Exclusive Breastfeeding in Bunda
} Maternity Clinic Surabaya

\author{
Devina Callista Ayungga ${ }^{1(\mathrm{CA})}$, Risa Etika ${ }^{2}$, Eighty Mardiyan Kurniawati ${ }^{3}$ \\ ${ }^{1(\mathrm{CA})}$ Faculty of Medicine, Universitas Airlangga, Indonesia; devinacallysta@ gmail.com (Corresponding Author) \\ ${ }^{2}$ Department of Pediatrics, Dr. Soetomo General Hospital, Indonesia; risa-etika@fk.unair.ac.id \\ ${ }^{3}$ Department of Obstetrics and Gynecology, Dr. Soetomo General Hospital, Indonesia; eighty- \\ mk@fk.unair.ac.id
}

\begin{abstract}
Background: The percentage of infants who receive exclusive breastfeeding in Indonesia can be much higher. There are many factors including working mothers. Aim: To find out if there is a significant relationship between working mothers towards exclusive breastfeeding. Methods: This study was an analytic observational study done using the data acquired from a questionnaire given to mothers who come to Bunda Maternity Clinic in Surabaya. Data was then analysed statistically using Chi square test. Result: Out of 20 working mothers, 6 $(30 \%)$ of them exclusively breastfed their infants while the rest did not. Out of 37 non-working mothers, 28 $(76 \%)$ of them exclusively breastfed their infants. A p-value of $p<0.001$ was obtained using the chi square test. Conclusion: There is a significant relationship between working mothers towards exclusive breastfeeding in Bunda Maternity Clinic Surabaya.
\end{abstract}

Keywords: exclusive breastfeeding; working mother

\section{INTRODUCTION}

\section{Background}

Breast milk is a source of nutrition that is species-specific and its composition is different from other source of nutrition that is usually used to replace breast milk. The nutrition in breast milk such as mineral, vitamin, and protein tend to be higher compared to the nutrition contained in an infant formula. Breast milk is also much easier to be digested by an infant. Infants given with breast milk have lower risks of developing asthma, allergy, diabetes, obesity, respiratory tract infection, and digestive tract infection ${ }^{(1)}$. In the long term, the procedure of breastfeeding can be useful for the mother as well to reduce the risk of the mother having type-2 diabetes mellitus, breast cancer, and ovarium cancer ${ }^{(2)}$.

Exclusive breastfeeding is a procedure recommended by WHO, the procedure of giving breastmilk as the sole source of nutrition for the infant without giving other food or fluid until the infant is six months old ${ }^{(3)}$. In Indonesia, exclusive breastfeeding is regulated by law which states that every infant has the right to be given exclusive breastfeeding since birth for six months, with the exception of medical indications. However, in Indonesia, only $54 \%$ infants were given exclusive breastfeeding in $2016^{(4)}$. In East Java and Surabaya, only $48 \%$ and $65.10 \%$ infants were given exclusive breastfeeding in 2016 , respectively ${ }^{(5)}$. The percentage of infants given exclusive breastfeeding could be and should be much higher.

The success of exclusive breastfeeding might be affected by several factors, one of them is working mothers. Working, which demands a mother to leave the house and her family for a certain amount of time each day will surely disturb the process of breastfeeding. In Indonesia, from the total of 115 millions of working people, $38 \%$ of them are female workers and 25 millions female workers are in their reproductive age ${ }^{(6)}$. 


\section{Purpose}

This study was done in order to find out the relationship between working mothers towards exclusive breastfeeding.

\section{METHODS}

This study was an analytic observational study using cross-sectional design at Bunda Maternity Clinic Surabaya in May 2019. Population included all mothers who came to Bunda Maternity Clinic Surabaya in May 2019 with samples being mothers who had a child aged 6-24 months old and agreed to be a subject of this study. The independent variable in this study included the employment status of the mother, whereas the dependent variable in this study included the exclusive breastfeeding status. Data was acquired through a questionnaire given to the subjects and were then analysed using Chi Square test by using SPSS. This study was approved by the Research and Development Department in Surabaya Health Office.

\section{RESULTS}

The 91 willing respondents were obtained in Bunda Maternity Clinic in Mei 2019. Out of 91 data, 57 data fulfilled the criteria to be included as samples while the rest are excluded. Results are presented as tables shown below.

Table 1. Distribution of study subjects according to age group

\begin{tabular}{ccc}
\hline Age & Frequency & Percentage \\
\hline$<20$ & 4 & 7.02 \\
$20-35$ & 49 & 85.96 \\
$>35$ & 4 & 7.02 \\
\hline Total & 57 & 100 \\
\hline
\end{tabular}

In this study, the youngest age of the subject is 17 years old and the oldest is 41 years old. The average age of study subjects is 27.26. The majority of subjects are aged 20-35 years old (85.96\%).

Table 2. Distribution of study subjects according to last educational background

\begin{tabular}{ccc}
\hline Last education & Frequency & Percentage \\
\hline No formal education & 0 & 0 \\
Elementary school & 4 & 7.02 \\
Junior high school & 16 & 28.07 \\
High school & 31 & 54.38 \\
Higher education (D3, D4, S1, S2, S3) & 6 & 10.53 \\
\hline Total & 57 & 100 \\
\hline
\end{tabular}

The majority of subjects are high school graduates $(54.38 \%)$. There is no subject whom did not receive formal education, while $7.02 \%$ of subjects' last formal education was elementary school, $28.07 \%$ junior high school, and $10.53 \%$ of subjects finished higher education.

Table 3 shows the distribution of the subjects' employment status during the infant's first six-month of age. In this study, 20 (35.09\%) mothers were employed during the infants' six-month of age while the rest were unemployed. 
Table 3. Distribution of study subjects according to employment status

\begin{tabular}{ccc}
\hline Employment status & Frequency & Percentage \\
\hline Employed (Employee worker, or self-employed) & 20 & 35.09 \\
Unemployed & 37 & 64.91 \\
\hline Total & 57 & 100 \\
\hline
\end{tabular}

Table 4. Distribution of exclusive breastfeeding status

\begin{tabular}{ccc}
\hline Exclusive breastfeeding status & Frequency & Percentage \\
\hline Exclusively breastfeed & 34 & 59.65 \\
Non-exclusively breastfeed & 23 & 40.35 \\
\hline Total & 57 & 100 \\
\hline
\end{tabular}

According to the table, out of 57 subjects, 34 (59.65\%) subjects exclusively breastfed their infants while the rest $(40.35 \%)$ didn't breastfeed their infants exclusively.

Based on the results of this study, $20(35.09 \%)$ subjects were working mothers while $37(64.91 \%)$ were unemployed during the infants' first six-month of age. From 37 subjects who were unemployed, 28 (75.68\%) subjects exclusively breastfed their infants while 9 (24.32\%) did not. Meanwhile, out of 20 working mothers, only $6(30 \%)$ working mothers exclusively breastfed their infants while the rest (70\%) did not.

Table 5. Relationship between working mothers towards exclusive breastfeeding in Bunda Maternity Clinic

\begin{tabular}{|c|c|c|c|c|c|c|c|}
\hline \multirow{3}{*}{ Variable } & \multicolumn{4}{|c|}{ Exclusive breastfeeding status } & \multicolumn{2}{|c|}{ Total } & \multirow{3}{*}{$P$ value } \\
\hline & \multicolumn{2}{|c|}{$\begin{array}{c}\text { Exclusively } \\
\text { breastfed }\end{array}$} & \multicolumn{2}{|c|}{$\begin{array}{c}\text { Non-exclusively } \\
\text { breastfed }\end{array}$} & \multirow[t]{2}{*}{$\mathrm{n}$} & \multirow[t]{2}{*}{$\%$} & \\
\hline & $\mathrm{f}$ & $\%$ & $\mathrm{f}$ & $\%$ & & & \\
\hline \multicolumn{8}{|c|}{ Mother's employment status } \\
\hline Unemployed & 28 & 75.68 & 9 & 24.32 & 37 & 100 & \multirow{3}{*}{$<0.001$} \\
\hline Employed & 6 & 30.00 & 14 & 70.00 & 20 & 100 & \\
\hline Total & 34 & 59.65 & 23 & 40.35 & 57 & 100 & \\
\hline
\end{tabular}

The relationship between working mothers towards exclusive breastfeeding in Bunda Maternity Clinic is analysed using a statistical hypothesis test called Chi square $\left(\mathrm{x}^{2}\right)$, with confidence interval of $95 \%(\alpha=0.05)$ between the variables. From the test, the value $p<0.001$ is obtained. Since the p value is less than 0.05 , it can be concluded that there is a significant relationship between working mothers and exclusive breastfeeding.

\section{DISCUSSION}

In this study, 34 (59.65\%) subjects out of 57 subjects in Bunda Maternity Clinic breastfed their infants exclusively. This percentage has met Renstra's target which was $44 \%{ }^{(7)}$. However, this percentage is still lower than the national percentage of infants that receive exclusive breastfeeding which reached $61.33 \%{ }^{(8)}$.

There are many factors that can influence exclusive breastfeeding, including internal and external factors. One factor is discussed in this study, which is working mothers. In this study, only $6(30 \%)$ subjects of working mothers exclusively breastfed their infants while the remaining $14(70 \%)$ subjects of working mothers did not exclusively breastfeed their infants. Most of the subjects who did not exclusively breastfeed their infants chose to mix breast milk with formula milk, but there were also some who did not give breast milk at all and chose to only give formula milk for their infants.

This is quite unfortunate seeing WHO has recommended that infants under six months should be exclusively breastfed so that both the mother and the infant can receive the numerous benefits from breastfeeding $^{(3)}$. According to AAP, infants who are breastfed have lower risk of developing asthma, allergy, 
diabetes, obesity, respiratory tract infection, and digestive tract infection ${ }^{(1)}$. For the mothers, the procedure of breastfeeding can also reduce the risk of women developing type-2 diabetes, breast cancer, and ovarian cancer. In addition, breastfeeding can also be a mean of bonding between the mother and the infant to create an emotional connection between the two ${ }^{(2)}$.

The low percentage of working mothers who exclusively breastfed their infants can be influenced by the limited amount of time the working mothers have in order to breastfeed their infants. Mothers who work will certainly have less time with their infants compared to mothers who do not. In a study conducted by Kartika, it showed that the subjects of mothers who work more than 8 hours all do not exclusively breastfeed their infants ${ }^{(8)}$. Aside from the limited amount of time, this can also occur because mothers who work for long periods of time might feel to tired to breastfeed their infants and prefer to give formula milk instead ${ }^{(9)}$. Contrasting with Kartika's study, no significant relationship was found between the length of time the mother works and exclusive breastfeeding in Abdullah's study ${ }^{(10)}$. However, in the study, the percentage of mothers who work less than 10 hours and give exclusive breastfeeding remains greater $(65.9 \%)$ than the percentage of mothers who work more than 10 hours.

In addition to the length of time a mother works, IDAI mentioned that the duration of break time during working also affects exclusive breastfeeding ${ }^{(11)}$. Article 79 Indonesian Law No.13 of 2003 about labour law mentions workers should have at least half an hour of break time after working for four hours continuously. According to Abdullah, that duration is not enough for working mothers to pump their breast milk ${ }^{(10)}$.

IDAI also mentions another factor with might affect exclusive breastfeeding which is the availability of facilities for pumping breast milk at the working place ${ }^{(11)}$. A study conducted by Amalia states that there is a significant relationship between the availability of facilities at the working place and exclusive breast feeding ${ }^{(12)}$. It also states that the availability of lactation room is a very important factor to support the success of exclusive breastfeeding. Another study conducted by Paramita states otherwise, in which it didn't find any significant relationship between the availability of a lactation room and exclusive breastfeeding ${ }^{(13)}$. However, it might happen because in the study, almost every work places the respondents work at don't provide lactation rooms.

The support of superiors and partners at the workplace also affects exclusive breastfeeding. This support can be shown by making a policy which gives working mothers an easier way to provide breast milk for the infants, for example by giving breastfeeding working mothers more break time so they can pump their breast milk, by giving them a more flexible annual leave, or by providing a lactation room at the workplace.

In this study, out of 57 subjects, 20 of them are working mothers. From 20 working mothers, only 6 (30\%) working mothers exclusively breastfed their infants while the remaining $14(70 \%)$ working mothers did not exclusively breastfeed their infants. Using a statistical test called Chi square, $\mathrm{p}$ value of $<0.001$ was obtained so it can be concluded that there is a significant relationship between working mothers and exclusive breastfeeding.

\section{CONCLUSION}

There is a significant relationship found between working mothers and exclusive breastfeeding in Bunda Maternity Clinic. Further study with larger samples and a different method might be required in order to confirm the result of this study.

\section{REFERENCES}

1. American Academy of Pediatrics. Breastfeeding and the use of human milk. Pediatrics. 2012;129(3).

2. Leung AKC, Sauve RS. Breast is best for babies. Journal of the National Medical Association. 2005;97:1010-1019

3. World Health Organization. Exclusive breastfeeding for optimal growth, development and health of infants. WHO [Internet]. 2018. Available from: https://who.int/elena/titles/exclusive_breastfeeding/en/

4. Kemenkes RI. Health profile of Indonesia in 2016 (Profil kesehatan Indonesia 2016) [Internet]. 2016. Available from: https://www.kemkes.go.id/resources/download/pusdatin/lainlain/Data\%20dan\%20Informasi\%20Kesehatan\%20Profil\%20Kesehatan\%20Indonesia\%202016\%20$\% 20 \% 20$ smaller\%20size\%20-\%20web.pdf

5. Dinkes Kota Surabaya. Surabaya City health profile in 2016 (Profil kesehatan Kota Surabaya tahun 2016). Surabaya: Dinkes Kota Surabaya; 2016.

6. BPS. Indonesia statistic in 2013 (Statistik Indonesia 2013). Jakarta: BPS; 2013.

7. Kemenkes RI. Strategic planning of the health ministry 2015-2019 (Rencana strategis Kementerian Kesehatan RI tahun 2015-2019) [Internet]. Kemenkes RI. 2015. Available from: https://www.kemkes.go.id/resources/download/info-publik/Renstra-2015.pdf 
8. Kartika RP. Relationship between a lactating mother's working time with breastfeeding in babies aged 0-6 months in bangsri jepara (Hubungan lamanya jam kerja ibu menyusui dengan pemberian ASI pada bayi usia 0-6 bulan di desa bangsri kecamatan bangsri kabupaten jepara). Jurnal Kesehatan dan Budaya. $2015 ; 8$.

9. Oktora R. The description of exclusive breastfeeding in working mothers in Serua Indah village, Jombang sub-district, South Tangerang (Gambaran pemberian asi eksklusif pada ibu bekerja di desa Serua indah, kecamatan jombang, tangerang selatan). Jurnal Kesehatan Reproduksi. 2013;4.

10. Abdullah G. Determinant of exclusive breastfeeding in working mothers in Indonesia health ministry (Determinan pemberian ASI eksklusif pada ibu bekerja di Kemenkes RI). Jakarta: Universitas Indonesia; 2013.

11. IDAI. Accomplishing breastfeeding during working (Sukses menyusui saat bekerja) [Internet]. Ikatan Dokter Anak Indonesia. 2013. Available from: https://www.idai.or.id/artikel/klinik/asi/sukses-menyusuisaat-bekerja-2

12. Amalia R. Factors which influence the success rate of working mothers giving exclusive breastfeeding (Faktor faktor yang mempengaruhi keberhasilan ibu bekerja dalam pemberian ASI eksklusif). Mandala of Health a Scientific Journal. 2018;11.

13. Paramita I. Relationship between a mother's occupation type with the success rate of exclusive breastfeeding during the first six months in Rangkah community health center, Surabaya (Hubungan antara jenis pekerjaan ibu dengan keberhasilan pemberian ASI eksklusif 6 bulan pertama di puskesmas Rangkah Surabaya). Surabaya: Universitas Airlangga; 2016. 